REGE

25,2

212

Received 23 June 2017 Accepted 6 February 2018

\section{Project management office in non-governmental organizations: an ex post facto study}

\author{
Adonai Lacruz \\ Instituto Federal do Espirito Santo, Viana, Brazil, and \\ Everton Cunha \\ Faculdade Estácio de Sá de Vila Velha, Vila Velha, Brazil
}

\begin{abstract}
Purpose - The purpose of this paper is to explore the influence of project management offices (PMO) in non-governmental organizations (NGOs), in fundraising linked to projects, under the theoretical lens of the resource-based view.

Design/methodology/approach - Through a longitudinal analysis ex post facto study in a non-profit civil association, the authors examined by Mann-Whitney's U tests the results before (2003-2008) and after (2009-2014) PMO implementation, to check if the office moderated the relationship between project management and fundraising for projects.

Findings - Mann-Whitney's U tests showed that PMO had, in those periods, a statistically significant influence in increasing the number of projects and decreasing the mean value of their budgets $(p$-value $<0.05)$.

Originality/value - Despite the wide range of studies on the contribution of PMOs to internal project management, there is a lack of empirical evidence on their moderation capacity, especially in NGOs. To fill this research gap, this study investigates the moderating role of PMO in NGOs, by examining their performance on fundraising processes, to contribute to a better understanding of potential PMO effects, particularly as a moderator of the relationship between project management and projects' fundraising.
\end{abstract}

Keywords Project management office, Non-governmental organizations, Resource-based view,

Ex post facto study

Paper type Research paper

\section{Introduction}

Many non-governmental organizations (NGOs) carry out their actions through projects related to their institutional mission (Diallo and Thuillier, 2004). The establishment of organizational units called project management offices (PMOs) has contributed to improve projects' performance (Golini et al., 2014).

NGOs financing can be considered a "donation market" (Glaeser, 2003, p. 15), with movements similar to those on stock exchanges. Public and private organizations offer resources for the development of NGOs' projects, usually by examining proposals submitted in response to public notices. These funds tend to be smaller than NGOs' demands, thus creating competition between these organizations. To deal with this situation, they tried to professionalize their management processes (Silva, 2010; Alvarez, 2009), and PMOs have proved to be a useful unit (Project Management Institute (PMI), 2013), with a central role in the search for resources, since its main objective is to make project management more efficient (Stanleigh, 2006).

(C) Adonai Lacruz and Everton Cunha. Published in the Revista de Gestão. Published by Emerald Publishing Limited. This article is published under the Creative Commons Attribution (CC BY 4.0) licence. Anyone may reproduce, distribute, translate and create derivative works of this article (for both commercial and non-commercial purposes), subject to full attribution to the original publication and authors. The full terms of this licence may be seen at http://creativecommons.org/licences/by/4.0/legalcode 
Fundraising is a critical stage for NGOs. For instance, the directory Análise Gestão Ambiental shows that 97 percent of the resources for environmental NGOs in Brazil, in (2013), came from donations linked to projects (Análise Gestão Ambiental (AGA), 2015), which demonstrates that NGOs' operation is mostly guaranteed by fundraising. Thus, a PMO is an organizational resource that supports this operation (Bates, 1998), by enabling the development and implementation of standards, methods, training and team support (Block and Frame, 1998), while providing capabilities (McKelvie and Davidsson, 2009) that are essential in the competition for financial resources.

We can consider a PMO as an internal strategic resource of the organization, more specifically a source of sustainable competitive advantage for fundraising in the donation market, by providing useful organizational skills (Barney and Hesterly, 2007) for its institutional objectives.

Under the theoretical lens of the resource-based view (RBV), an organizational structure perspective described in Barney and Hesterly (2007), resources can create a sustainable competitive advantage when they become organizational competencies. PMOs, as an internal strategic resource, can provide a sustained competitive advantage in the management of third sector projects, by turning this resource into an organizational competence.

Literature on this matter is rich: it shows that project management has a positive influence on project performance (Joslin and Müller, 2015; Liu, 2015; Yazici, 2009); it describes it with different guidelines (Project Management Body of Knowledge, International Project Management Association Competence Baseline, Prince 2, ISO 21.500 Guidance on Project Management, PMD Pro, PM4DEV, etc.); and it analyzes PMOs' moderating role during ten year-periods (Jalal and Koosha, 2015; Liu and Yetton, 2007). However, we found only a few studies that address NGOs (Lacruz, 2015; Golini et al., 2014; Gomes, 2014).

In addition, we did not find empirical studies on the performance of fundraising processes for projects. Research on third sector projects is a critical issue, especially on this specific stage, since such organizations carry out their actions mainly through projects financed by different donors, in order to accomplish their institutional mission (Lacruz, 2014).

Brazilian studies generally address the discussion of project performance through a triple internal constraint (cost, time and scope), using a cross-section analysis that limits the disclosure of potential PMO moderation capacity, and mainly from studies of private for-profit organizations (Barbalho et al., 2014; Cianfanelli and Pessoa, 2014; Martins et al., 2011).

Despite the wide range of studies on the contribution of PMOs to internal project management (Jalal and Koosha, 2015; Lacruz, 2015; Liu and Yetton, 2007; Dai and Wells, 2004), there is a lack of empirical evidence on their moderation capacity, especially in NGOs. This study seeks to contribute to a better understanding of potential PMO effects, particularly as a moderator of the relationship between project management and projects' fundraising.

To fill this research gap, this study investigates the moderating role of PMO in NGOs, by examining their performance on fundraising processes. We conducted a longitudinal analysis ex post facto, in order to answer the following question: do PMOs in NGOs affect the performance of projects' fundraising?

We investigated this hypothetical relationship in a third sector organization, given the lack of public data. Although we could establish causal relations between variables, the purpose of the study was not to explain why or how the facts happened, but rather to explore those facts by pointing out to a possible causal link based on evidence.

The relevance of this study lies in the potential contribution to theory of the analysis of PMO performance, which is a well-researched topic in project management (Joslin and Müller, 2015; Jalal and Koosha, 2015; Golini et al., 2014), from the perspective of fundraising, a typical stage in the life cycle of third sector projects (Lacruz, 2014). It is an open question whether PMO moderates the relationship between project management and fundraising in the third sector. If proved, this relationship may serve as evidence for other studies, with explanatory research designs, to investigate the relationship between PMOs and metrics of fundraising. 
REGE

25,2

214

\section{Theoretical background}

In order to build a theoretical basis for the analyses and discussions, this section approaches the RBV and PMOs in NGOs.

\section{The $R B V$}

RBV can be used to analyze the influence of PMOs on NGO fundraising for projects. This perspective on organizational structure states that organizational resources can create sustainable competitive advantage when they become organizational competencies.

The literature on organizational strategy considers two paradigms that explain a superior sustainable performance. The first rests on the concepts of industrial organization (McGrath et al., 1995), and the second perspective says that companies are essentially idiosyncratic from the standpoint of organizational economics. The latter corresponds to $\mathrm{RBV}$, in which there is a connection between an organization's internal attributes and its competitive performance (Barney, 1991).

A relevant RBV contribution is that it shows the attributes that allow an organization to achieve superior performance over a long period, since they do not depend on industry conditions. Another benefit of this theory lies in its usefulness for managers that seek to understand, keep or expand their competitive advantage (Peteraf, 1993). Therefore, strategic management under RBV enables organizations to create economic value from heterogeneity, by acquiring and developing resources and capabilities.

The vast diversity of studies reveals that there are subtle but relevant differences in the definition of resources (Amit and Schoemaker, 1993; Daft, 1983; Hoskisson et al., 2009; Wernerfelt, 1984). In this article, according to most studies regarding project management and RBV, we use Daft's (1983) definition: "resources are understood as assets, capacities, organizational processes, attributes, knowledge, information, etc., that the organization controls and that allow it to create and implement strategies that improve its performance."

Based on the categorizations of several authors, Barney (1991) divided resources in three classes of capital: human, physical, and organizational capital. Human capital relates to training, relationships, experience, intelligence, critical capacity and contributions from managers and employees. Physical capital comprises the technology used in the organization, its plant and equipment, its geographic location and its access to raw materials and inputs. Organizational capital refers to management, including its structure of formal reports, formal and informal planning, control and coordination systems, as well as the informal relationships between different groups in the organization and between the firm and the external environment.

According to RBV, organizations' different performances result from the variability of their resources and capabilities (Hitt et al., 2001; Powell, 1995). An organization can outperform its competitors by implementing strategies, but the cost of acquiring/keeping the resources that support such strategies should be significantly less than their economic value, allowing the organization to exploit competitive imperfections in strategic factors' markets (Barney, 1986).

Several authors (Amit and Schoemaker, 1993; Hitt et al., 2001; Peteraf, 1993) agree that positive returns achieved by organizations are the result of the interaction between their resources and their strategies, and that both strategy and organizational structure affect the organization's economic performance and the market where it operates. For RBV, organizational success stems from the economic value of resources, inimitable by other organizations, and for which there are no substitutes (Powell, 1995).

Barney (1991, p. 107) stated: "It is not difficult to see that valuable and rare organizational resources may be a source of competitive advantage." However, as he explains, not all resources of an organization have the potential to create competitive advantage. To do this, a resource must have four attributes: be valuable, rare, imperfectly imitable, and imperfectly substitutable. 
This author highlighted two issues that became the axioms of RBV: resources are spread heterogeneously across organizations; and resources are non-transferable between organizations without an additional cost. Based on these axioms, he concluded that valuable and rare resources are capable of creating a competitive advantage, while those that are both inimitable and irreplaceable provide the basis for a sustained competitive advantage.

Barney (1991), together with Hesterly, reviewed the four essential attributes of resources and reshaped them slightly. In the new proposition, they kept the first three attributes practically unchanged (value, rarity, imperfect imitability), while they totally altered the last one (imperfect substitutability) for "organization." Thus, Barney and Hesterly (2007) propose that the key attributes of resources that create a sustainable competitive advantage are: valuable, rare, costly to imitate and organized to exploit.

Both approaches (Barney and Hesterly, 2007; Barney, 1991) argue that there are competitive advantages that can provide the organization with a superior performance over its competitors, as they build strategies for value creation that are difficult to adopt by other companies without additional costs, thus preventing imitation. If competitors cannot copy such strategies in the short term, the organization will achieve a sustainable competitive advantage.

By comparing the two approaches, there is a subtle distinction regarding resource characterization. Barney and Hesterly (2007) move from the idea of substituting resources to favor their organizations. Despite having valuable and rare resources, as well as capabilities that are difficult to imitate, the firm will only gain competitive advantage if these resources are properly organized. They observe that, among the distinct components of a firm, these organization-related aspects stand out: remuneration policy, hierarchical arrangement, and formal and informal systems of management and control.

There are similarities between the structural focus of Barney and Hesterly (2007) and Nadler's (1993) proposition of organizational architecture, which considers that business' processes, structures and strategies are directly related to the behavioral space of action of the individuals that work in the organization (Fernandino and Oliveira, 2010).

Nadler and Tushman (1993) observe that organizational architecture comprises both the formal and informal structure of the organization, and directly relates it to the ability of implementing business strategies. In this sense, it allows the exploration of a resource with potential to create a sustainable competitive advantage. From this viewpoint, Barney and Hesterly (2007) recommend that organizations should evaluate their current or potential resources according to the four attributes, in order to demonstrate their capacity to become a sustainable competitive advantage over their rival companies.

Hence, we can examine PMO through the "Organization" resource attribute, since its primary objective is to provide the company with capabilities that allow it to develop and exploit the potential of its resources. Thus, we can define a PMO as an internal strategic resource of the organization, capable of providing a sustainable competitive advantage in project management, since such a unit allows the organization to differentiate itself through its organizational competencies and add value to its product/service (Jugdev et al., 2007).

Therefore, we assume that PMOs in NGOs enable the organizations to combine their capabilities and resources in an integrated way, providing them with a sustainable competitive advantage in the market of project-related donations.

\section{The third sector and PMO}

The third sector in Brazil comprehends civil society activities that do not fall under the first (public administration) or second (for-profit companies) sectors. They include organizations such as political parties, associations and non-profit foundations, unions, professional councils, religious organizations, etc. (Instituto Brasileiro de Geografia e Estatística (IBGE), 2012), which requires a delimitation of these entities. In this study, the objects of interest are non-profit private associations and foundations, which are commonly known as NGOs. 
REGE

25,2

216

IBGE conducts periodical surveys of these organizations, named the private foundations and non-profit associations in Brazil (FASFIL). The most recent survey, from 2010, revealed the existence of 290,700 private non-profit associations and foundations in the country, which represented 5 percent of the universe of these organizations. Their workforce was composed of more than 2.1 million employees, covering about 7 percent of the salary mass (IBGE, 2012).

Most of their initiatives are implemented through projects (Diallo and Thuillier, 2004) supported by agreements and contracts with private companies, business institutes, family institutes, public and other third sector organizations (Lacruz et al., 2017). Thus, the project, whose conceptual definition is "a temporary effort to generate a specific delivery" (PMI, 2013; Muriana and Vizzini, 2017), refers to the "object" of the contractual relationship between the third sector entity and the donor organization. It regards the venture carried out within a defined period, with defined scope, quality and cost, as a counterpart to the donation, subject to the norms of the contract (or a similar instrument) between the parties.

Grupo de Institutos, Fundações e Empresas Network, which gathers 125 private social investors from Brazil, allocated more than 3 billion reais to projects in 2014. The demands of the supporters have grown gradually, as the volume of resources increased (Golini et al., 2014). The nominal growth rate of the funds offered by this network was 18.5 percent between 2009 and 2014 (Grupo de Institutos Fundações e Empresas, 2015).

NGOs generally raise funds linked to projects, for activities related to their institutional mission, by submitting project proposals to donors; and they also gather resources not related to specific projects, which are expenses of the organization, through commercial processes (sales of products and services), auctions, fundraising dinners, crowdfunding, etc. (Lacruz et al., 2017). In this study, we focused on donations related to projects.

The motivation for NGOs to adopt market management practices (Tenório, 1999) stems partly from the dynamism of the historical trajectory of NGOs' qualification (Silva, 2010), which made them shift from a fundamentally philanthropic model to a corporate one, in a process named by Salamon (1997) as "marketization."

As a consequence, the corporate model brings together partnerships that trigger temporary organizational arrangements (Bakker et al., 2016), to coordinate activities resulting from partnerships with organizations, businesses, states, foundations, and associations, as well as other NGOs (arising from fundraising in the donation market). The more intense competition for public and private resources compels NGOs to professionalize their processes and management models (Lacruz et al., 2017), through project management, in general, and $\mathrm{PMO}$ in particular, in order to become more competitive.

Organizations have established and integrated units, typically known as PMOs, into their organizational structures. These are considered innovative and highly effective (Alexandrova et al., 2015), in an effort to manage their projects more effectively (Pellegrinelli and Garagna, 2009; Jalal and Koosha, 2015). This has also happened with some NGOs (Golini et al., 2014; Crawford, 2002; Dinsmore, 1999).

In this study, we assumed that the theoretical framework of RBV is appropriate to analyze NGOs' behavior, and we concentrated on the set of resources and competencies that belong to these organizations, or were externally acquired. In this perspective, we examined PMOs as an internal strategic resource of the organization that can provide a sustainable competitive advantage in project management. We understood that combining the organization's resources intentionally and rationally (from the perspective of the attribute "resource organization") is a strategic action that contributes to the achievement of organizational goals in projects of the donation market, thereby attaining a sustainable competitive advantage (Barney and Hesterly, 2007).

Block and Frame (1998) were the first to emphasize the importance of creating a business unit, generally referred to as a project office, to support the formal management of projects in 
organizations. According to the Project Management Body of Knowledge guide (PMBOK $\left.{ }^{\circledR}\right)$, "a project management office (PMO) is a management structure that standardizes the project-related governance processes and facilitates the sharing of resources, methodologies, tools, and techniques" (PMI, 2013, p.10).

This definition sets its central objective in guiding and supporting project managers, allowing the organization to develop its projects in the most efficient and effective way. In general, several PMO concepts address the importance of project management maturity in organizations. The common focus of PMO definitions is that they are business units that coordinate the organization's project management, providing standardized training, software, and policies (Aubry et al., 2008, 2010; Crawford, 2002; Kerzner, 2003). Thus, by including another business unit, regardless of its level - corporate, divisional, sectoral or departmental -, the organization will not add an expense center[1] but rather a cost center to support the revenue centers and contribute to savings in the supply of products or services linked to the projects. Nevertheless, as Barcaui and Quelhas (2004) observed, in a survey conducted with 116 Brazilian companies, most PMOs were created as a reaction to financial losses in the execution of projects.

PMOs' performance analysis considers the results of projects coordinated by them, or during the phases of project life cycle under their responsibility. Project performance is a well-researched topic in project management, but the meaning of the term "performance" varies substantially. It can relate to a project's external objectives, measured by stakeholders' satisfaction, especially in the third sector, from the perspective of beneficiaries, donors and partners; or to project management, measured at the end, through its internal efficiency in terms of cost, quality of delivery, and expectations (Cooke-Davies and Arzymanow, 2003; Golini et al., 2014; Ika et al., 2012). The classic internal management indicators of a project (cost, time and quality) are those for which NGOs are directly accountable to donors (Hermano et al., 2013).

Project performance involves the management processes described under different guidelines, such as PMBOK, International Project Management Association Competence Baseline, Prince 2, ISO 21.500 Guidance on Project Management, among others. Some guidelines were created especially for the management of international NGO development projects, where PMD Pro and PM4DEV are the best known. A comparison between these specific methodologies shows that PMD Pro and PM4DEV tools are very similar to PMBOK guidelines (Hermano et al., 2013), which is the best known guideline in Brazil. Methodologies for the third sector were developed mainly from this reference and from the project's life cycle (Gomes, 2014; Lacruz, 2014; Xavier and Chueri, 2008).

The tools and techniques proposed for NGO management processes tend to be less complex. Golini et al. (2014) carried out a study on the adoption of PMBOK, PMD Pro and PM4DEV tools and project management techniques, with 496 third sector organizations that prepare international development projects, and they showed that these organizations are more likely to adopt simpler techniques (such as logic matrix and progress reports) than analytical methodologies (such as value-added techniques). In the cluster analysis performed by the authors, four stages of maturity were defined, resulting from the adoption of different levels of tools and techniques by the organizations, which suggest a learning cycle in project management, from the identified stages.

The methodologies adapted for the third sector generally extend the traditional life cycle of projects (initiation, planning, execution, monitoring and control and closure), considering two capital phases for NGOs: fundraising and accountability (Lacruz, 2014), as shown in Figure 1.

The fundraising phase involves identifying opportunities, preparing proposals, negotiating and contracting; while during the accountability phase organizations send reports to the donors regarding project execution, and its physical and financial performance. The Brazilian Accounting Standards (NBC ITG 2002/2012, NBC T 10.19/2000 \& NBC T 10.4/1999) define 
REGE

25,2

218

that the acknowledgment of the expenses and revenues from the activities of these entities, in the income statements, occurs when the donor approves the accountability. Until it happens, they appear in the balance sheet, as a debt contracted at the time of fundraising, which will be settled on accountability.

Many studies show that project management has a positive effect on project performance (Joslin and Müller, 2015; Liu, 2015; Yazici, 2009), and in the last ten years the moderating role of PMOs grew in relevance (Jalal and Koosha, 2015; Unger et al., 2012; Liu and Yetton, 2007).

A PMO is a center of excellence that implements practices and standardizes project-related governance processes, facilitating the sharing of resources, methodologies, tools and techniques among various projects (PMI, 2013), with the main goal of improving the effectiveness of project management (Stanleigh, 2006). Previous studies, under the RBV perspective, consider PMO as an important explicit resource for managing project assets (Yogarajah, 2017).

Thus, PMOs gather project management resources in a structured and coordinated way, but distinct PMOs can have different roles and functions (Hobbs and Aubry, 2008). Given the operational features of PMO in our study, it involves tangible (templates) and intangible resources (mentoring), which, in the third sector, together comprise the resource attributes that result in a sustainable competitive advantage, according to RBV: valuable, rare, costly to imitate and organized to exploit.

This understanding is different from what Jugdev et al.(2007) suggest for private for-profit organizations. In these, while PMO is a valuable and organized resource, it is not uncommon or costly to imitate. Therefore, under RBV, a sustainable competitive advantage could not result from it. However, it is different with third sector projects, where a PMO is rare, particularly in Brazil: the PMI Survey revealed that only 2 percent of NGOs had a PMO in their organizational structure (PMI chapter, 2012). Given its rareness, it is difficult to imitate. Thus, we can suggest that a PMO has the four attributes that build a sustainable competitive advantage.

There is evidence to assume that PMOs contribute to improve project management (Yogarajah, 2017), and that project management, in turn, positively affects project performance (Joslin and Müller, 2015). In addition, PMO moderates the relationship between project management and project performance metrics (Jalal and Koosha, 2015).

Nevertheless, if not all project management resources have capabilities that result in a sustainable competitive advantage (Jugdev et al., 2007), some questions regarding PMO still remain. Being an organizational unit that coordinates project management resources (Yogarajah, 2017), does it moderate the relationship between these resources and the performance metrics of the sources of sustainable competitive advantage, especially fundraising in the third sector?

We found few studies that address fundraising as a specific metrics of performance, especially in the third sector (Biesenthal et al., 2012; Golini et al., 2014; Gomes, 2014; Lacruz, 2015). However, we found no study regarding fundraising performance linked to projects[2]. This gap led to the research question: do PMOs in NGOs affect the performance of projects' fundraising?

\section{Description of the selected NGO}

The third sector organization that we studied is Instituto Terra, a NGO founded in 1998. Its areas of action are ecosystem restoration and environmental education, and its priority

Figure 1.

Generic phases of projects' life cycle in the third sector

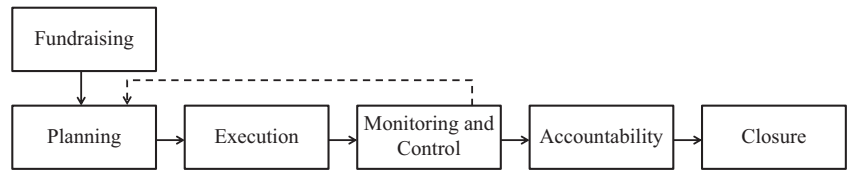

Source: Adapted from Lacruz (2014, p. 38) 
geographic field of operation is the Vale do Rio Doce (between the states of Minas Gerais and Espirito Santo). Some activities include the production of Atlantic Forest seedlings, dissemination of environmental programs, and applied scientific research. It promotes and carries out actions by fundraising, mainly through project proposals (rather than transferring funds to third parties and monitoring their progress). The projects have national and foreign donors: public, private for-profit organizations, and other third sector institutions. It is one of the largest environmental NGOs in Brazil (AGA, 2015), and has received worldwide recognition for its work on spring protection (Gazeta Online, 2016).

We justify its choice for three main reasons: it develops a large part of its actions through projects, for which it gets funds in the donation market (Glaeser, 2003); it has relationships with a diversity of donors from different segments, such as government agencies, business foundations, private companies and other NGOs, both national and international; and it was a pioneer in the Brazilian third sector in the implementation of a corporate PMO (Lacruz, 2010; PMI chapter, 2012).

Before PMO implementation, Instituto Terra's organizational structure was functional. Afterwards, it became a matrix. PMO is situated at the tactical level, lateral to the other departments (business units divided according to the institution's areas of activities), and reports directly to the CEO. The organizational design matches a functional structure with some kind of departmentalization of units of temporary projects (during the period of the contract).

After reviewing the organization's strategic planning, and relying on PMBOK, the establishment of PMO began in 2009, with the integration of the management areas of cost, time and scope.

PMO was conceived as a guiding unit with the following activities: development, implementation and support to the methodology, as well as to the project management tool; preparation of project proposals; project monitoring and control, and definition and monitoring of performance indicators; sharing of performance reports and documents; and support to the management of shared resources.

PMO functions are more closely associated with the stages of fundraising, monitoring and accountability (Figure 1). In the course of its operation, management comprised other areas mentioned in PMBOK (communications, acquisitions, risks, quality, human resources and stakeholders), besides project auditing and portfolio management, with the resulting expansion of PMO's functions.

\section{Method}

This exploratory study has a quantitative approach and uses a longitudinal analysis to investigate the effect of establishing PMO in a NGO, on projects' fundraising, which characterizes it as an ex post facto research.

Ex-post facto research is an appropriate method for the analysis of natural experiments (Chapin, 1947). This study fits into this method, since it assesses the potential moderating role of PMO (exogenous event) in the relationship between project management (explanatory variable) and fundraising (explained variable), under the analytical perspective of RBV (theoretical lens).

For McMillan and Schumacher (2006), an ex post facto study explores the existence of relationships between variables that the researcher cannot control, since their manifestations already took place, and the study is done after the occurrence of changes in the dependent variable without a direct control over the independent variables. The researcher makes inferences about the relations observed between the variables, from the simultaneous variation between the independent and dependent variables.

In order to explore PMO's influence, we chose two moments in the organization: six years before its implementation (2003-2008) and six years after it (2009-2014). The sources of 
REGE

25,2

220

evidence used to get several measures of the same phenomenon, during the analysis stage, were the annual activity reports and NGO's audited financial statements.

Depending on the macroeconomic scenario, a larger availability of projects can affect fundraising, and the organization can capture funds for several projects, regardless of PMO. Thus, we used the annual gross domestic product (GDP) with current prices as the control variable in the model, in order to minimize potential effects that could confuse PMO's influence. Other social variables, such as the Gini Index or the Human Development Index, which also have an impact, were not included in order to avoid multicollinearity problems. Figure 2 shows the research scheme.

The study explores PMO influence on the performance of fundraising processes in terms of number of projects and their budgets. Performance scores of the variable "project budget" were determined in order to cushion the value of money over time, considering the mean Extended Consumer Price Index during the period 2003-2014 as the discount rate (5.91 percent per year) (Instituto Brasileiro de Geografia e Estatística, 2015). Table I describes the criteria and their calculation.

The small sample size (six years before and six years after PMO implementation) has limitations regarding the use of data processing techniques. For this reason, we checked if the performance scores after PMO establishment were different from the pre-implementation scores, by using the Mann-Whitney's non-parametric hypothesis test, which is appropriate for small samples $(n<30)$. However, we could not satisfactorily verify if the numerical variable could result from a variable with normal distribution. We used SPSS 20 and GPower 3.1 software for data processing.

\section{Results and discussion}

Before starting the extraction of measures, we characterize the variables.

We observe a higher mean and a lower data dispersion in the period after PMO implementation, in relation to the approved number of projects. Data dispersion before implementation corresponds to 36 percent of the mean, whereas after it is only 8 percent. Thus, we can suggest that PMO contributed to a higher stability of the fundraising process and brought important benefits to NGOs, which get better conditions for planning, with less

Figure 2.

Nomothetic model

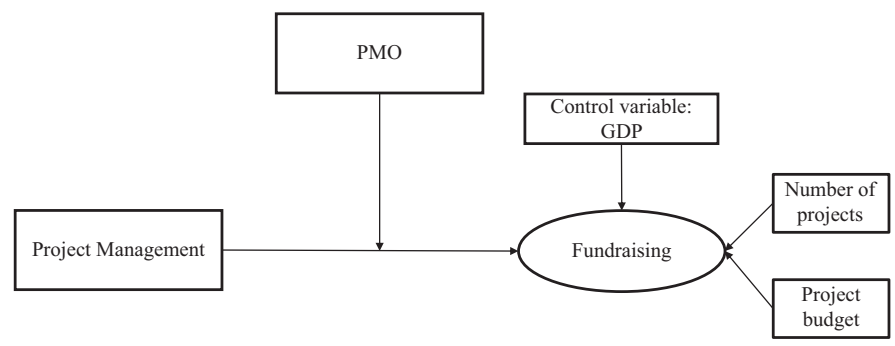

\begin{tabular}{lll}
\hline Criteria & Description & Formula \\
\hline Fundraising for projects & Annual number of approved projects \\
& Annual mean of the approved projects' budgets & $\begin{array}{l}F_{j} \\
\sum_{t=1}^{n} P \times(1+i)^{t} / F_{j} \\
P=\text { budget } \\
i=\text { discount rate } \\
t=\text { generic period }(1 ; \mathrm{n})\end{array}$
\end{tabular}

Table I.

Performance score description 
risk associated to forecasting. Regarding the projects' budget, the mean of the period after PMO implementation is lower than in the previous period, and dispersion is similar (17 and 19 percent of the mean, respectively). Therefore, we can sense that PMO contributed to reduce the mean value of all projects.

According to the classification criterion proposed by Cohen (1988), for differences between independent group means $(d>0.79)$, the effect sizes can be considered large for number of projects and project budget ( $d=4.63$ and $d=1.87$, respectively).

We explored the relationships between GDP at annualized market prices, the number of projects funded $(\rho=0.796)$, and the mean budget of projects $(\rho=0.456)$, by the Spearman correlation coefficient $\rho$. Since we cannot assume that data follow a normal distribution, we observed that there was not a statistically significant correlation ( $p$-value $>0.05$ ); thus we can assume that GDP variation did not affect the number of projects funded or the mean budget of projects during that period.

Finally, we conducted the Mann-Whitney's non-parametric U test for independent samples, and observed that there was sufficient evidence to refute the null hypothesis. We found a different performance before and after PMO implementation $(p$-value $<0.05)$ for both variables: number of projects funded $(p$-value $=0.002)$ and mean projects' budget $(p$-value $=0.009)$. Statistical power $(1-\beta)$ was 0.97 for the number of projects, and 0.81 for the mean budget of projects, above the threshold $(>0.8)$ from which the value is consensually considered appropriate (Hair et al., 2009). For the calculation of statistical power, we determined the effect size by Cohen's $d$ (see Table II).

PMOs influence on fundraising linked to projects, regarding the number of projects, is positive, since the mean after PMO implementation is higher than before $(22.3>9.7)$; while the influence regarding the mean budget of projects is negative, because the mean in the second period is lower than in the first period $(585<830)$, as shown in Table II. Therefore, results show that PMO had a statistically significant influence, both regarding the increase in the number of projects and the decrease of their mean value.

By concentrating the processes of fundraising, monitoring and control in a specific organizational unit dedicated to these activities, it was possible to identify more opportunities and to prepare and submit project proposals more in line with the donors' interests (associated with the function "elaboration of project proposals"). In addition, the management of multiple projects of the same nature (programs) allows integrated acquisition processes, which result in economies of scale in the procurement and hiring processes (associated to the function "support for shared management of resources"). Moreover, it facilitates corrective measures in projects' processes (associated with the function "project monitoring and control,"

\begin{tabular}{|c|c|c|c|c|}
\hline Projects & Before implementation & & After implementation & \\
\hline \multicolumn{5}{|c|}{ Fundraising - number of projects } \\
\hline Mean & 9.7 & & 22.3 & \\
\hline Minimum & 5 & & 21 & \\
\hline Maximum & 15 & & 25 & \\
\hline SD & 3.4 & & 1.8 & \\
\hline Effect size & & Cohen's $d=4.63$ & & \\
\hline \multicolumn{5}{|c|}{ Fundraising - project budget (in thousands of reais) } \\
\hline Mean & 830 & & 585 & \\
\hline Minimum & 666 & & 444 & \\
\hline Maximum & 1,025 & & 660 & Table II. \\
\hline $\mathrm{SD}$ & 156 & & 100 & Descriptive statistics \\
\hline Effect size & & Cohen's $d=1.87$ & & and effect size \\
\hline
\end{tabular}

\section{Project management office}


REGE

25,2

222

"definition and monitoring of performance indicators," and "sharing of performance reports and documents").

If, on one hand, the lower mean value of the projects is a positive aspect, since it allows the organization to access the donations market more easily, with an efficiency gain, on the other hand the reduction in the mean value may reflect a decrease in the quality of project results. Or, in other words, in worse social services related to projects.

Spearman's correlation coefficient shows a statistically significant negative linear relationship $(\rho=-0.808$ I $p$-value $=0.001)$, suggesting that the higher the number of projects the lower their mean value (see Table II). Finally, the costs behind these benefits are worth questioning: has the increase in the number of projects and the reduction of their mean cost resulted from higher administrative expenses? Based on the overhead margin (percentage of administrative expenses in relation to the expenses with activities, extracted from the yearly income statements), there is a strong reduction after PMO implementation, as shown in Figure 3.

The mean of the pre-implementation period was 29 percent and standard deviation was 9 percent (30 percent of the mean), while the mean after implementation was 11 percent, and standard deviation 1 percent (9 percent of the mean). By plotting a trend line in Figure 3, we see that the results after PMO establishment are lower than shown in the trend line, thus strengthening PMO's contribution to reduce the overhead margin. That is, PMO not only did not increase the overhead margin, but also reduced it substantially (63 percent).

\section{Conclusion}

RBV provides inputs to examine the behavior of a third sector organization, by concentrating on the set of resources and competences, intrinsic or externally acquired. In the development of the study, we analyzed PMO as an internal strategic resource that can provide a sustained competitive advantage in project management.

The proposed analytical framework, regarding the contributions identified in the study on project fundraising, suggests that PMO is an inductor of project management maturity, according to Rodrigues et al. (2006). These contributions can be associated with processes used in multiple projects to provide organizations with past experiences, which allow them to transfer knowledge from one project to another, replicating successful actions and seeking alternatives for the unsuccessful. These results add up to Julian's (2008) findings, since the addressed PMO centralizes the coordination of all the organization's projects.

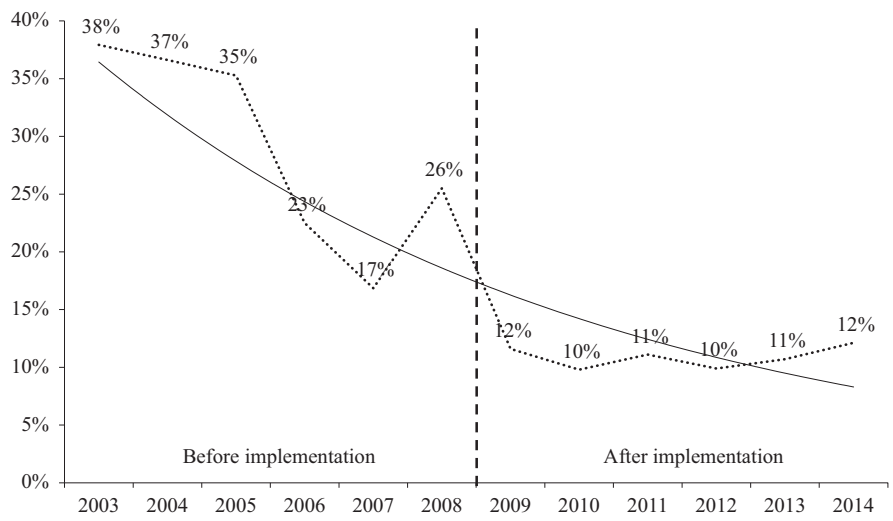

Figure 3.

Overhead margin
Notes: The dotted line represents the overhead margin; the continuous line, the trend; and the dashed line perpendicular to the abscissa separates the period before and after PMO implantation 
Results also highlight the positive relationship between PMO implementation and the increase in the number of projects and in fundraising. That is, the organization benefited from the increase in the global budget and in the corresponding reduction of the seasonality of activities related to projects, thus achieving cost reduction in project management, as well as reduction of risks associated to the intensive use of capital. However, there may be other effects on dependent variables that we did not analyze. As mentioned, the organization implemented PMO after reviewing its strategic planning to provide support for tactical and operational plans. Other internal variables that resulted from this process, and whose effects we could not isolate, due to the nature of the study (ex post facto), may have affected the results that suggest differences between the periods, either directly or through their interaction with PMO. Furthermore, this study relies solely on a particular organization, which limits the generalization of results. Therefore, we need caution to interpret these results. As McMillan and Schumacher (2006) noticed, in ex post facto studies the usual results are the confirmation of relations between variables, rather than assuring cause-effect relationships. Our results may serve for future studies that have access to data from a larger number of NGOs that use PMO in their organizational structures.

Even if we could not establish a cause-effect relationship between PMOs and fundraising, we suggest this possibility, which should be sought in future studies. Given the lack of consistent empirical support on this matter, this paper tried to fill the gap by exploring the influence of PMO in NGO fundraising.

Another limitation regards the feasibility of PMO implementation, considering economic and financial aspects. The overhead margin analysis alone does not lead to a satisfactory conclusion, despite its evident reduction after PMO establishment. Unfortunately, it was not possible to measure classical indicators of feasibility analysis (such as net present value, internal rate of return, etc.), through differential cash flow due to the lack of access to PMO-specific expenses, since data are not presented by cost centers, but consolidated for the whole organization.

We suggest that NGOs' motivation to adopt project management practices in general, and PMOs specifically, results partly from partnerships with business organizations, state organizations, business foundations and associations, and other NGOs (as a result of fundraising), since they need organizational arrangements to coordinate the activities resulting from these partnerships. According to Alvarez (2009), in Latin America this process is called "NGO-ization" of social movements. Hence, a more intense competition for public and private resources stimulates the professionalization of NGO management processes, among them the adoption of project management practices, in search of higher efficiency, which drives them to shift from a philanthropic model to a corporate one (Alvarez, 2009; Silva, 2010).

For new studies and a greater reach of the conclusions, judging from the results and limitations of this study, future research should use a mixed research method (Creswell and Clark, 2013) to enhance the analysis, with both qualitative information (raised by in-depth interviews) and quantitative information (through questionnaires). Further research can explore PMO implications for other performance metrics such as project governance, beneficiaries' satisfaction, partners, and donors. Moreover, researchers could examine the differences between NGOs of different sizes (volume of resources received) and areas of interest (health, environment, education, sports, etc.).

Thus, the results bring three important advances to the area: first, from the theoretical standpoint, it demonstrates the moderating role of PMO in the performance of fundraising processes linked to projects. Although some studies showed the influence of PMO on internal project management (Jalal and Koosha, 2015; Lacruz, 2015; Liu and Yetton, 2007; Dai and Wells, 2004), studies on NGOs are a research gap. Second, from a practical perspective, some NGOs have found that PMOs are an alternative for improving project 
REGE

25,2

224

performance (Golini et al., 2014; Gomes, 2014; Lacruz, 2015), and these findings contribute to the assessment of cost opportunity. third, from a methodological perspective, we demonstrated the effect size (Cohen's $d$ ), which allows other studies to compare the mean effectiveness of the model developed in this study, in their research area, which brings a practical significance to the effect size.

Finally, we expect that this research will collaborate with future studies in building plans for PMO implementation and evaluation in NGOs.

\section{Notes}

1. The difference between cost center and expense center refers to the link of costs with generation of results (deliverables), while expenditures exist regardless of results.

2. We conducted a bibliographic research in SciELO database, searching the use of the term "project" combined one by one to "donation" and "fundraising," in the papers' abstracts, without using filters.

\section{References}

Alexandrova, M., Stankova, L. and Gelemenov, A. (2015), "The role of project office for project portfolio management”, Economic Alternatives, Vol. 1, pp. 19-30, available at: https://ideas.repec.org/a/ nwe/eajour/y2015ilp19-30.html

Alvarez, S. (2009), "Beyond NGO-ization? Reflections from Latin America”, Development, Vol. 52 No. 2, pp. $175-184$.

Amit, R. and Schoemaker, P.J.H. (1993), "Strategic assets and organizational rent", Strategic Management Journal, Vol. 14 No. 1, pp. 33-46.

Análise Gestão Ambiental (AGA) (2015), Anuário 2013, Autor, São Paulo.

Aubry, M., Hobbs, B. and Thuillier, D. (2008), "Organisational project management: an historical approach to the study of PMOs", International Journal of Project Management, Vol. 26 No. 1, pp. 38-43.

Aubry, M., Müller, R., Hobbs, B. and Blomquist, T. (2010), "Project management offices in transition", International Journal of Project Management, Vol. 28 No. 8, pp. 766-778.

Bakker, R.M., DeFillippi, R.J., Schwab, A. and Sydow, J. (2016), “Temporary organizing: promises, processes, problems", Organization Studies, Vol. 37 No. 12, pp. 1703-1719.

Barbalho, S.C.M., Toledo, J.C.de, Rojic, J. and Sillos, M.deA. (2014), "Funções dos escritórios de projetos no desenvolvimento de produtos: pesquisa-ação em empresa de alta tecnologia”, Producion, Vol. 24 No. 2, pp. 322-336.

Barcaui, A. and Quelhas, O. (2004), "O perfil de escritório de gerenciamento de projetos em organizações atuantes no Brasil”, Revista Pesquisa E Desenvolvimento Engenharia De Produção, Vol. 2 No. 1, pp. 38-53.

Barney, J. (1986), "Strategic factor markets: expectations, luck, and business strategy", Management Science, Vol. 32 No. 10, pp. 1231-1241.

Barney, J. (1991), "Firm resources and sustained competitive advantage", Journal of Management, Vol. 17 No. 1, pp. 99-120.

Barney, J. and Hesterly, W.S. (2007), Administração estratégica e vantagem competitiva, Person Prentice Hall, São Paulo.

Bates, W. (1998), "Improving project management”, IIE Solutions, Vol. 30 No. 10, pp. $42-43$.

Biesenthal, C., Vignehsa, K., Sankaran, S., Pitsis, T., Gudergan, S., Clegg, C. and Anandakumar, A. (2012), "Tools of change: exploring the duality of dynamic capabilities in project-based organizations", European Group for Organizational Studies, available at: https://opus.lib.uts.edu.au/bitstream/10 453/30367/1/EGOS_Chris_Submission_V5_010612_final.doc (accessed March 9, 2018). 
Block, T.R. and Frame, J.D. (1998), The Project Office: A Key to Managing Projects Effectively, Crisp publications, Menlo Park, CA.

Chapin, F.S. (1947), Experimental Designs in Sociological Research, Harper, New York, NY.

Cianfanelli, M.M. and Pessoa, L.C. (2014), "Escritório de gerenciamento de projetos - elo organizacional entre o estraégico e o operacional: um estudo de caso", Revista Cientifica Hermes, Vol. 12, pp. 53-76, available at: www.redalyc.org/service/redalyc/downloadPdf/4776/477647159004/6

Cohen, J. (1988), "A power primer”, in Kazdin, A.E. (Ed.), Methodological Issues and Strategies in Clinical Research, APA, Washington, DC, pp. 339-348.

Cooke-Davies, T.J. and Arzymanow, A. (2003), "The maturity of project management in different industries: an investigation into variations between project management models", International Journal of Project Management, Vol. 21 No. 6, pp. 471-478.

Crawford, J.K. (2002), The Strategic Project Office, Marcel Deker, New York, NY.

Creswell, J.W. and Clark, V.L.P. (2013), Pesquisa de métodos mistos, Penso, Porto Alegre.

Daft, R.L. (1983), Organization Theory and Design, West, New York, NY.

Dai, C.X. and Wells, W.G. (2004), "An exploration of project management office features and their relationship to project performance", International Journal of Project Management, Vol. 22 No. 7, pp. 523-532.

Diallo, A. and Thuillier, D. (2004), "The success dimensions of international development projects: the perceptions of African project coordinators", International Journal of Project Management, Vol. 22 No. 1, pp. 19-31.

Dinsmore, P.C. (1999), Winning in Business with Enterprise Project Management, Amacon, New York, NY.

Fernandino, J.A. and Oliveira, J.L. (2010), "Arquiteturas organizacionais para a área de P\&D em empresas do setor elétrico Brasileiro", Revista de Administração Contemporânea, Vol. 14 No. 6 , pp. 1073-1093.

Gazeta online (2016), "Mil nascentes já estão protegidas no rio Doce", October 1, available at www. gazetaonline.com.br/noticias/cidades/2016/09/mil-nascentes-ja-estao-protegidas-no-rio-doce-10 13981825.html (accessed March 9, 2018).

Glaeser, E.L. (2003), Introduction to: The Governance of not-for-profitorganizations, The University of Chicago Press, Chicago, IL.

Golini, R., Kalchschmidt, M. and Landoni, P. (2014), "Adoption of project management practices: the impact on international development projects of non-governmental organizations", International Journal of Project Management, Vol. 33 No. 3, pp. 650-663.

Gomes, C.F.S. (2014), "Estruturação de um departamento de gestão de projetos no terceiro setor: estudo de caso na ONG Viva Rio", Relatórios de pesquisa em engenharia de produção, Vol. 14 No. 6 , pp. $52-70$.

Grupo de Institutos Fundações e Empresas (2015), Censo GIFE 2014, GIFE, São Paulo.

Hair, J.F., Black, W.C., Babin, B.J., Anderson, R.E. and Tatham, R.L. (2009), Análise multivariada de dados, Bookman, Porto Alegre.

Hermano, V., López-Paredes, A., Martín-Cruz, N. and Pajares, J. (2013), "How to manage international development (ID) projects successfully: is the PMD Pro1 guide going to the right direction?", International Journal of Project Management, Vol. 31 No. 1, pp. 22-30.

Hitt, M.A., Bierman, L., Shimizu, K. and Kochhar, R. (2001), "Direct and moderating effects of human capital on strategy and performance in professional service firms: a resource-based perspective", Academy of Management Journal, Vol. 44 No. 1, pp. 13-28.

Hobbs, B. and Aubry, M. (2008), "An empirically grounded search for typology of project management offices”, Project Management Journal, Vol. 39 No. 1, pp. 69-82.

Hoskisson, R.E., Hitt, M.A., Ireland, R.D. and Harrison, J.S. (2009), Estratégia competitiva, Cengage Learning, São Paulo. 
REGE 25,2

Jalal, M.P. and Koosha, S.M. (2015), "Identifying organizational variables affecting project management office characteristics and analyzing their correlations in the Iranian project-oriented organizations of the construction industry", International Journal of Project Management, Vol. 33 No. 2, pp. 458-466.

Joslin, R. and Müller, R. (2015), "Relationships between a project management methodology and project success in different project governance contexts", International Journal of Project Management, Vol. 33 No. 6, pp. 1377-1392.

Jugdev, K., Mathur, G. and Fung, T.S. (2007), "Project management assets and their relationship with the project management capability of the firm", International Journal of Project Management, Vol. 25 No. 6, pp. 560-568.

Julian, J. (2008), "How project management office leaders facilitate cross-project learning and continuous improvement", Project Management Journal, Vol. 39 No. 3, pp. 43-58.

Kerzner, H. (2003), "Strategic planning for a project office", Project Management Journal, Vol. 34 No. 2, pp. 13-25.

Lacruz, A.J. (2010), "Escritório de projetos em organização sem fins lucrativos: estudo de caso", Anais do $10^{\circ}$ Seminário Internacional de Gerenciamento de Projetos, São Paulo, available at: https://pt.scribd.com/document/304917871/Estudo-de-caso-PMI

Lacruz, A.J. (2014), "Gestão de projetos no terceiro setor: uma proposta de metodologia para associações e fundações privadas sem fins lucrativos", Mundo Project Management, Vol. 57, pp. 34-40, available at: http://projectdesignmanagement.com.br/produto/gestao-de-projetos-noterceiro-setor/

Lacruz, A.J. (2015), "Project management office in nonprofit firms: an application in NGO instituto Terra in Brazil", Business and Management Review, Vol. 4 No. 5, pp. 510-523.

Lacruz, A.J., Moura, R.L. de and Rosa, A.R. (2017), "Organizando à sombra dos doadores: novas tendências de governança corporativa das ONGs na América Latina”, Anais da $11^{a}$ Conferência Regional da ISTR para América Latina e Caribe, Quito, available at: www.istrlac.org/uploads/4/ 4/7/9/44790215/lacruz_moura_e_rosa_-_area_tematica_3.pdf

Liu, L. and Yetton, P. (2007), "The contingent effects on project performance of conducting project reviews and deploying project management offices", IEEE Transactions on Engineering Management, Vol. 54 No. 4, pp. 789-799.

Liu, S. (2015), "Effects of control on the performance of information systems projects: the moderating role of complexity risk", Journal of Operations Management, Vol. 36, pp. 46-62, available at: www.sciencedirect.com/science/article/pii/S0272696315000200

McGrath, R.G., MacMillan, I.C. and Venkataraman, S. (1995), "Defining and developing competence: a strategic process paradigm”, Strategic Management Journal, Vol. 28 No. 4, pp. 251-275.

McKelvie, A. and Davidsson, P. (2009), "From resource base to dynamic capabilities: an investigation of new firms", British Journal of Management, Vol. 20 No. S1, pp. S63-S80.

McMillan, J.H. and Schumacher, S. (2006), Research in Education: Evidence-Based Inquiry, Pearson, Boston, MA.

Martins, H.C., Moura, M.T. and Mesquita, J.M.C. de (2011), "Escritório de projetos como resposta estratégica da organização: um estudo de caso na vale", Revista gestão e produção, Vol. 2 No. 2 , pp. 26-54.

Muriana, C. and Vizzini, G. (2017), "Project risk management: a deterministic quantitative technique for assessment and mitigation", International Journal of Project Management, Vol. 35 No. 3, pp. 320-340. 
Nadler, D.A. (1993), "Arquitetura organizacional: metáfora para mudança”, in Nadler, D.A., Gerstein, M.S. and Shaw, R.B. (Eds), Arquitetura Organizacional: a Chave Para a Mudança Empresarial, Campus, Rio de Janeiro, pp. 1-8.

Nadler, D.A. and Tushman, M.L. (1993), "Projetos de organizações com boa adequação: uma moldura para compreender as novas arquiteturas", in Nadler, D.A., Gerstein, M.S. and Shaw, R.B. (Eds), Arquitetura organizacional: a chave para a mudança empresarial, Campus, Rio de Janeiro, pp. 39-56.

Pellegrinelli, S. and Garagna, L. (2009), "Towards a conceptualisation of PMOs as agents and subjects of change and renewal", International Journal of Project Management, Vol. 27 No. 7, pp. 649-656.

Peteraf, M.A. (1993), “The cornerstones of competitive advantage: a resource-based view”, Strategic Management Journal, Vol. 14 No. 3, pp. 179-191.

PMI Chapters (2012), "PMSURVEY.ORG 2012 edition", Brazil report, available at: www.pmsurvey.org (accessed March 9, 2018).

Powell, T.C. (1995), “Total quality as competitive advantage: a review and empirical study”, Strategic Management Journal, Vol. 16 No. 1, pp. 15-37.

Project Management Institute (PMI) (2013), A Guide to the Project Management Body of Knowledge, PMI, Newtown Square, PA.

Rodrigues, I., Rabechini Júnior, R. and Csillag, J.M. (2006), “Os escritórios de projetos como indutores de maturidade em gestão de projetos", Revista de administração da USP, Vol. 41 No. 3, pp. 273-287.

Salamon, L.M. (1997), Holding the Center: America's Nonprofit Sector at a Crossroads, Foundation Center, New York, NY.

Silva, C.E.G. (2010), "Gestão, legislação e fontes de recursos no terceiro setor brasileiro: uma perspectiva histórica”, Revista de administração pública, Vol. 44 No. 6, pp. 1301-1325.

Stanleigh, M. (2006), "From crisis to control: new standards for project management", Ivey Business Journal, Vol. 70 No. 4, pp. 1-4.

Tenório, F.C. (1999), "Um espectro ronda o terceiro setor: o espectro do mercado", Revista de Administração Pública, Vol. 33 No. 5, pp. 85-102.

Unger, B.N., Gemünden, H.G. and Aubry, M. (2012), "The three roles of a project portfolio management office: their impact on portfolio management execution and success", International Journal of Project Management, Vol. 30 No. 5, pp. 608-620.

Wernerfelt, B. (1984), “A resource-based view of the firm”, Strategic Management Journal, Vol. 5 No. 2 , pp. 171-180.

Xavier, C.M. da S. and Chueri, L. de O.V. (2008), Metodologia de gerenciamento de projetos no Terceiro Setor, Brasport, Rio de Janeiro.

Yazici, H.J. (2009), "The role of project management maturity and organizational culture in perceived performance”, Project Management Journal, Vol. 40 No. 3, pp. 14-33.

Yogarajah, N. (2017), "A resource-based perspective on project management in non-governmental organisations (NGOs): a study of NGOs in Sri Lanka", Tese de doutorado, Bournemouth University, Dorset, Inglaterra, available at: http://eprints.bournemouth.ac.uk/29262/1/ YOGARAJAH\%2C\%20Nanthagopan_Ph.D._2017.pdf (accessed March 9, 2018).

\section{Corresponding author}

Adonai Lacruz can be contacted at: adonai.lacruz@ifes.edu.br

For instructions on how to order reprints of this article, please visit our website:

www.emeraldgrouppublishing.com/licensing/reprints.htm

Or contact us for further details: permissions@emeraldinsight.com 